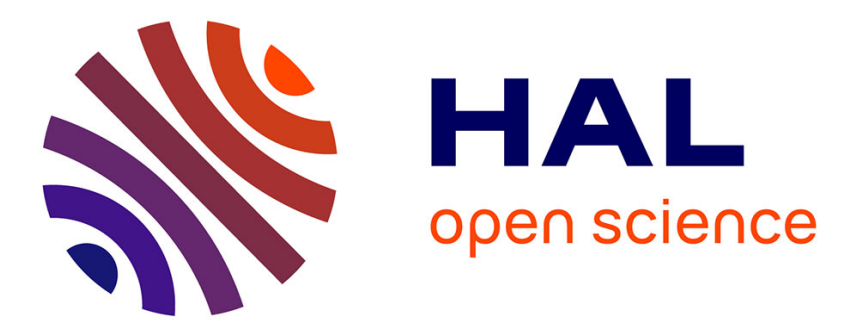

\title{
Residential air conditioning and heating by means of enhanced solar collectors coupled to an adsorption system
}

\author{
Marc Clausse, Khurshid C.Amanul Alam, Francis Meunier
}

\section{To cite this version:}

Marc Clausse, Khurshid C.Amanul Alam, Francis Meunier. Residential air conditioning and heating by means of enhanced solar collectors coupled to an adsorption system. Solar Energy, 2008, 10.1016/j.solener.2008.04.001 . hal-02079150

\section{HAL Id: hal-02079150 \\ https://hal.science/hal-02079150}

Submitted on 25 Mar 2019

HAL is a multi-disciplinary open access archive for the deposit and dissemination of scientific research documents, whether they are published or not. The documents may come from teaching and research institutions in France or abroad, or from public or private research centers.
L'archive ouverte pluridisciplinaire HAL, est destinée au dépôt et à la diffusion de documents scientifiques de niveau recherche, publiés ou non, émanant des établissements d'enseignement et de recherche français ou étrangers, des laboratoires publics ou privés. 


\title{
RESIDENTIAL AIR CONDITIONING AND HEATING \\ BY MEANS OF ENHANCED SOLAR COLLECTORS COUPLED TO AN \\ ADSORPTION SYSTEM \\ M. Clausse*, K.C.A Alam, F. Meunier
}

Laboratoire de Génie des Procédés pour l’Energie, l’Environnement et la Santé (LGP2ES - EA 21), Cnam

IFFI, case 331, 292 rue Saint-Martin, 75141 Paris Cedex 03, France

\begin{abstract}
This work explores the possibility to perform heating and air/conditioning of state of the art building located near Paris in France. For air/conditioning, enhanced compound parabolic solar collectors are used as heat source of an adsorption system (methanol/activated carbon), while during winter direct coupling with the building is performed.

A model describing the adsorption unit, the solar collectors and the house was used to simulate the performances of such an installation.

For air-conditioning, thermal comfort is achieved as indoor temperature is kept below $25{ }^{\circ} \mathrm{C}$ during five consecutive hot days (heat wave effect), contrarily to the case for which only free cooling during night-time is used. For heating, the indoor temperature remains below the comfort temperature value by $2 \mathrm{~K}$. Nevertheless, the auxiliary heating need will remain limited so that savings on electricity or fossil fuel consumption will be possible.
\end{abstract}

keywords: residential air-conditioning/heating, solar thermal energy, adsorption, numerical simulation

\section{Introduction}

\footnotetext{
* corresponding author

e-mail: clausse@cnam.fr

phone: (+33) (0)1 58808549

fax: (+33) (0)1 40272595
} 
Electricity generation and building are two sectors that are major contributors to $\mathrm{CO}_{2}$ emissions: $40 \%$ of EU energy consumption comes from the building sector (Balaras et al., 2007; Camelia, 2006). Lowering the $\mathrm{CO}_{2}$ emissions in the building sector is of major difficulty as the sources are small, disperse and depends heavily on the building structure. Furthermore, the demand for thermal air-conditioning is increasing: the annual energy use of room air conditioner was $6 \mathrm{TJ}$ (about $1.7 \mathrm{GWh}$ ) in 1990 and is estimated to reach $160 \mathrm{TJ}$ (about 44 GWh) in 2010 (Balaras et al., 2007).

Solar heating and air-conditioning is one possible way to reduce building fossil fuel consumption and greenhouse gas emission in low-energy buildings. Three technologies are available for solar heat driven air conditioning: absorption, adsorption and dessicant cooling. Among these technologies, absorption is the most widely used with $59 \%$ of the installed systems in Europe against 11\% for adsorption and 23\% for dessicant cooling (Henning, 2007). Adsorption chillers have lower COP than absorption ones but can work at lower driving temperature.

Different heat-driven cooling technologies are available on the market at capacities above $40 \mathrm{~kW}$. However, the use of smaller scale systems (a few $\mathrm{kW}$ ) in the residential/building sector implies further $R \& D$ work as nearly none of the mentioned technologies is available on the market at these small capacities (Balaras, 2007; Henning, 2007). Recently, a study was performed on the performances of an absorption unit of less than $10 \mathrm{~kW}$ (Argiriou et al., 2005). This study evaluates the interest of such a unit for two building types and different climates. Concerning the adsorption systems, studies are mainly about refrigeration applications and cycle enhancement (Dieng and Wang, 2001; Yong and Sumathy, 2004; Saha et al., 2003; Wang et al., 2005; Wang and Oliveira, 2006) without considering the whole system integration: the solar panels, the adsorption unit and the house. More recently, two articles reported work on the use of adsorption for solar air-conditioning. The first one 
focuses on the adsorption unit conception and performance (Nunez et al., 2007), while the second one presents field results form an installation in Shanghai (Zhai et al., 2007). In this last study, the solar system was able to contribute to $70 \%$ of the building total energy consumption for heating and air-conditioning (year basis).

Hence, in this work, which was part of the SoCold CRAFT EU contract, it was chosen to evaluate the performances of a small adsorption unit for residential air-conditioning. The system has the following main characteristics:

- the application is a $100 \mathrm{~m}^{2}$ house which complies with the French RT2000 building standards (about $120 \mathrm{kWh} / \mathrm{m}^{2} . \mathrm{y}$ for heating)

- no storage: the adsorption unit and the panels are directly connected during summer for air-conditioning while in winter the solar panel are connected to the floor to provide space heating

- The house is located in Orly France $\left(48^{\circ} 43^{\prime} \mathrm{N}, 02^{\circ} 23^{\prime} \mathrm{E}\right)$ as this type climate both heating and cooling needs

The complete system layout is illustrated in Fig. 1. It includes the solar system (Compound Parabolic Collectors), the adsorption machine and the floor heating/cooling system. It has to be noticed once again that contrarily to usual systems, all sub-systems are directly connected to each other without storage or control system to regulate the temperature. Indeed, one of the aims of the present work is to explore the benefit of such a system. Furthermore, to be competitive for integration in residential buildings, these systems have to be as simple as possible to lower their installation cost which is one of their main weakness today.

To calculate the performances of the installation, a numerical model of the solar panels, the adsorption unit and the house was developed. Thanks to this model, the installation ability to achieve thermal comfort requirements will be evaluated for five consecutive hot days during 
summer (heat waves phenomenon) for air-conditioning and five consecutive cold days during winter for heating.

\section{Installation description - mathematical model}

The following sections present the components in detail and the related equations.

\subsection{Adsorption unit}

The adsorption unit is made of two adsorbers and was developed for the SoCold project. The cycle is the basic cycle for refrigeration by adsorption: the adsorbers are alternatively connected to the solar panel/condenser loops and to the outdoor unit/evaporator loops. No mass or heat recovery is used to keep the system as simple and robust as possible. Hence, the adsorber cycle is divided into four steps: pre-heating, desorption, pre-cooling and adsorption. The duration of pre-heating and desorption steps is called the half-cycle time and it is of course equal to the duration of the pre-cooling and adsorption steps. More details on operating adsorption cooling unit can be found elsewhere in the literature (Meunier, 1998; Pons and Poyelle, 1999; Saha et al., 2003).

Although being more suitable for refrigeration (Critoph, 1988; Meunier, 1998, Dieng and Wang, 2001) methanol and AC-35 activated carbon (20 kg per adsorber) are used as working pair instead of the usual zeolite-silica gel/water pair for air conditioning (Poyelle et al., 1999, Meunier, 1998). Indeed, the methanol has higher pressure and density compared to water for the same operating conditions. This could be of interest in terms of robustness and cost reduction of the unit.

An outdoor dry air unit is used to evacuate the rejected heat at the condenser and the adsorber. 
The energy balance of the adsorbent bed during desorption is given as:

$$
\begin{aligned}
& \frac{d}{d t}\left\{\left(M_{a, M}+M_{a c}+M_{a c} q_{d} C_{p, M e O H}\right) T_{d}\right\}= \\
& \Delta H \cdot M_{a c} \frac{d q_{d}}{d t}+\dot{m}_{H W} C_{p, H W}\left(T_{H W, \text { out }}-T_{H W, \text { in }}\right)
\end{aligned}
$$

During the adsorption step, the sensible heat to increase the vapour from the evaporation temperature to the adsorption temperature is taken into account. Furthermore, the adsorber cooling temperature is taken equal to the ambient temperature increased by $10 \mathrm{~K}$ to take into account the pinch due to the outdoor unit.

$$
\begin{aligned}
& \frac{\mathrm{d}}{\mathrm{dt}}\left\{\left(\mathrm{MC}_{\mathrm{d}, \mathrm{M}}+\mathrm{MC}_{\mathrm{ac}}+\mathrm{M}_{\mathrm{ac}} \mathrm{q}_{\mathrm{a}} \mathrm{C}_{\mathrm{pl}, \mathrm{MeOH}}\right) \mathrm{T}_{\mathrm{a}}\right\}=\Delta \mathrm{H} \cdot \mathrm{M}_{\mathrm{ac}} \frac{\mathrm{dq}_{\mathrm{a}}}{\mathrm{dt}}+ \\
& \mathrm{MC}_{\mathrm{ac}} \mathrm{C}_{\mathrm{pv}, \mathrm{MeOH}} \frac{\mathrm{dq}_{\mathrm{a}}}{\mathrm{dt}}\left(\mathrm{T}_{\mathrm{ev}}-\mathrm{T}_{\mathrm{a}}\right)+\dot{\mathrm{m}}_{\mathrm{MW}} \mathrm{C}_{\mathrm{p}, \mathrm{MW}}\left(\mathrm{T}_{\mathrm{MW}, \text { in }}-\mathrm{T}_{\mathrm{MW}, \text { out }}\right)
\end{aligned}
$$

For the condenser and the evaporator the energy balances are:

$$
\begin{aligned}
& \frac{d}{d t}\left\{\left(M_{c d, M}+M_{c w}\right) T_{c d}\right\}=-L_{a c} \cdot M_{a c} \frac{d q_{d}}{d t} \\
& +M_{a c}^{c} c_{p v, M e O H} \frac{d q_{d}}{d t}\left(T_{c d}-T_{d}\right)+\dot{m}_{c d, w} c_{p, c d, w}\left(T_{w, c d, i n}-T_{w, c d, o u t}\right) \\
& \frac{d}{d t}\left\{\left(M_{e, M}+M_{e, M e O H}\right) T_{e}\right\}=-L \cdot M_{a c} \frac{d_{a}}{d t} \\
& +M_{\text {ac } C_{p l, M e O H}} \frac{d q_{d}}{d t}\left(T_{e}-T_{c d}\right)+\dot{m}_{C W} c_{p, C w}\left(T_{C W, \text { in }}-T_{C W, \text { out }}\right)
\end{aligned}
$$

In addition to the equations (1-4), the following equation is used to calculate the outlet temperature of the different water loops:

$$
\mathrm{T}_{\text {out }}=\mathrm{T}+\left(\mathrm{T}_{\text {in }}-\mathrm{T}\right) \cdot \exp \left(-\mathrm{UA} / \dot{\mathrm{mC}}_{\mathrm{p}}\right)
$$

Adsorption equilibrium is assumed and the Dubinin-Astakhov model is used (Leite and Daguenet, 2000): 


$$
\mathrm{q}=\mathrm{q}_{0} \cdot \rho_{1}(\mathrm{~T}) \cdot \exp \left(-\mathrm{D}\left[\mathrm{T} \cdot \ln \left(\frac{\mathrm{P}_{\text {sat }}}{\mathrm{P}}\right)\right]^{\mathrm{n}}\right)
$$

Parameters of the presented equations are summarized in Table 1.

The cyclic average cooling capacity (CACC) can be evaluated by the following expressions:

$$
\text { CACC }=\frac{\int_{\text {begin of cycle time }}^{\text {end of cycle time }} \dot{m}_{\text {chill }} C_{\text {chil, } f}\left(T_{\text {chill, in }}-T_{\text {chill,out }}\right) d t}{\text { Cycle time }}
$$

The cycle COP (Coefficient of Performance) can be calculated by the following equation:

$$
\mathrm{COP}_{\text {cycle }}=\frac{\int_{\text {begin of cycle time }}^{\text {end of cycletime }} \dot{m}_{\text {chill }} C_{\text {chil, } f}\left(T_{\text {chill,in }}-T_{\text {chill,out }}\right) d t}{\int_{\text {begin of cycle time }}^{\text {end of cycle time }} \dot{m}_{f} C_{f}\left(T_{d, \text { in }}-T_{d, \text { out }}\right) d t}
$$

Solar COP in a cycle $\left(\mathrm{COP}_{\mathrm{sc}}\right)$ can be expressed as the following expression:

$$
\mathrm{COP}_{s c}=\frac{\int_{\text {begin of cycle time }}^{\text {end of cycle time }} \dot{m}_{\text {chill }} C_{\text {chil, } f}\left(T_{\text {chill,in }}-T_{\text {chill,out }}\right) d t}{\int_{\text {begin of cycle time }}^{\text {end of cycle time }} n \cdot A_{\text {cr } I d t}}
$$

Where, $I$ is the solar irradiance and $A_{c r}$ is each collector area and $n$ is number of collector

\subsection{Solar system}

The heat source consists in ten enhanced compound parabolic concentrator (CPC) developed by Solarfocus-GmbH with a total gross area of $24.2 \mathrm{~m}^{2}$. An increase of $20 \%$ in efficiency is claimed by the manufacturer for these new CPC compared to classical ones. The efficiency $\eta_{\mathrm{sC}}$ of the CPC as a function of the ambient temperature, the solar radiation and the heating medium temperature is given by (manufacturer's data):

$$
\eta_{\mathrm{SC}}=0.75-2.57\left(\frac{\overline{\mathrm{T}}_{\mathrm{HW}}-\mathrm{T}_{\mathrm{am}}}{\mathrm{I}}\right)-4.67\left(\frac{\overline{\mathrm{T}}_{\mathrm{HW}}-\mathrm{T}_{\mathrm{am}}}{\mathrm{I}}\right)^{2}
$$


Where $\overline{\mathrm{T}}_{\mathrm{HW}}$ is the heat transfer fluid mean temperature: $\overline{\mathrm{T}}_{\mathrm{HW}}=\frac{\left(\mathrm{T}_{\mathrm{HW}, \text { in }}+\mathrm{T}_{\mathrm{HW} \text {, out }}\right)}{2}$ and I the solar radiation.

The energy balance for the solar collector is given by the following equation:

$$
\begin{aligned}
\frac{\mathrm{M}_{\mathrm{SC}} \mathrm{C}_{\mathrm{SC}} \mathrm{d} \overline{\mathrm{T}}_{\mathrm{SC}}}{\mathrm{dt}} & =\eta_{\mathrm{SC}} \mathrm{A}_{\mathrm{SC}} \mathrm{I}+\dot{\mathrm{m}}_{\mathrm{HW}} \mathrm{C}_{\mathrm{p}, \mathrm{HW}}\left(\mathrm{T}_{\mathrm{HW}, \text { in }}-\mathrm{T}_{\mathrm{HW}, \text { out }}\right) \\
\mathrm{I} & =\mathrm{I}_{\text {max }} \sin \left(\frac{\pi \cdot\left(\mathrm{t}-\mathrm{t}_{\text {sunrise }}\right)}{\mathrm{t}_{\text {sunset }}-\mathrm{t}_{\text {sunrise }}}\right)
\end{aligned}
$$

\subsection{House with floor heating/cooling system}

The energy balance for the house (eq. 13) and the floor (eq. 14) are written as follows:

$$
\begin{gathered}
\mathrm{MC}_{\text {house }} \frac{\mathrm{dT}_{\text {indoor }}}{\mathrm{dt}}=(\mathrm{UA})_{\text {wall }} \cdot\left(\mathrm{T}_{\text {amb }}-\mathrm{T}_{\text {indoor }}\right)+(\mathrm{UA})_{\text {win }} \cdot\left(\mathrm{T}_{\mathrm{amb}}-\mathrm{T}_{\text {indoor }}\right) \\
+(\mathrm{UA})_{\text {floor }} \cdot\left(\mathrm{T}_{\text {floor }}-\mathrm{T}_{\text {indoor }}\right)+\left(\rho \mathrm{C}_{\mathrm{p}}\right)_{\text {air }} \cdot \dot{\mathrm{V}}_{\text {fresh }}\left(\mathrm{T}_{\text {amb }}-\mathrm{T}_{\text {indoor }}\right)+\dot{\mathrm{Q}}_{\text {indoor }} \\
\mathrm{MC}_{\text {floor }} \frac{\mathrm{dT}_{\text {floor }}}{\mathrm{dt}}=(\mathrm{UA})_{\text {floor }} \cdot\left(\mathrm{T}_{\text {indoor }}-\mathrm{T}_{\text {florr }}\right)+\dot{\mathrm{m}}_{\mathrm{CW}} \mathrm{C}_{\mathrm{P}, \mathrm{CW}} \cdot\left(\mathrm{T}_{\mathrm{CW} \text {,out }}-\mathrm{T}_{\mathrm{CW} \text {,in }}\right)
\end{gathered}
$$

where $\dot{\mathrm{V}}_{\text {fresh }}$ is the fresh air flowrate imposed by the regulations. Two values are used: $200 \mathrm{~m}^{3} / \mathrm{h}$ for normal operation and $3000 \mathrm{~m}^{3} / \mathrm{h}$ when free cooling (night extra ventilation) is possible. The criterion to activate the free cooling is: $\mathrm{T}_{\text {indoor }} \geq \mathrm{T}_{\mathrm{amb}}+2 \mathrm{~K}$ (Argiriou et al., 2005).

$\dot{\mathrm{Q}}_{\text {indoor }}$ is the internal load due to the occupants and the equipment. Two cases are considered: from 8 a.m. until 10 p.m. it is equal to $1500 \mathrm{~W}$ while it is equal to $700 \mathrm{~W}$ taking into account the load decrease during night time. 
To simulate the house without adsorption cooling, eq. 14 is kept but the chilled water flowrate is set to 0 . It is also the case when the adsorption unit is not producing cold in order to disconnect it from the floor.

\section{Results and discussion for Air-Conditioning}

The Orly climatic data for a typical day of July are reported on Fig. 2. The maximum of solar radiation is about $800 \mathrm{~W} / \mathrm{m}^{2}$ while the ambient temperature reaches its maximum $\left(31^{\circ} \mathrm{C}\right)$ at 17h. The total solar energy received during one day is then $8.7 \mathrm{kWh} / \mathrm{m}^{2}$.d. It has to be noticed that the ambient temperature is still at $28^{\circ} \mathrm{C}$ at 10 p.m.. This annoyance is directly the cause of the lack of thermal comfort during summer.

The simulation was run for five consecutive warm days to investigate the solar adsorption system ability to maintain thermal comfort during heat waves. All results are given for day 5 .

\subsection{Adsorption unit performances}

For this study, the chosen half-cycle time is $1000 \mathrm{~s}$. The pre-heating and pre-cooling times are kept equal and worth around $300 \mathrm{~s}$ depending on the daytime. The thermodynamic performances of the adsorption unit are reported on Fig. 3. The cooling capacity, averaged on one cycle, peaks at $4.6 \mathrm{~kW}$ at 2 p.m.. It has to be noticed that thanks to the enhanced CPC, the cooling capacity is $1 \mathrm{~kW}$ at 8 a.m. although the solar radiation is only about $380 \mathrm{~W} / \mathrm{m}^{2}$. Cycle COP varies from 0.12 to 0.6 .

During one day, the total received solar energy is $211 \mathrm{kWh}$ for a total cold production of 42.7 $\mathrm{kWh}$. Hence, the day averaged solar COP is 0.2 . The day averaged value of the solar collector efficiency being about 0.41 , the averaged cycle COP is 0.49 . 
These values seem to be quite high compared to other cases (0.08 to 0.1 in Yong and Sumathy, 2004) but are in the ranges reported by Henning (2007). The difference can be explained by the used CPC's, which present increased efficiency compared to other solar collectors. Indeed, as it can be seen on Fig. 4, the maximum adsorbent temperature is about $130^{\circ} \mathrm{C}$ while only a maximum temperature of $70^{\circ} \mathrm{C}$ is reached in Yong and Sumathy (2004). Moreover, the mean value is already $55^{\circ} \mathrm{C}$ at 8 a.m. compared to $35^{\circ} \mathrm{C}$ at the same time in Yong and Sumathy (2004).

The same temperature evolutions as on Fig. 4 with the solar collector temperature between 1 p.m. and 2 p.m. are reported on Fig. 5 for one cycle. The outlet solar collector temperature decreases rapidly during the pre-heating/pre-cooling step as the solar panel are directly connected to the cold adsorber (alternatively A1 and A2). During the desorption step, the solar collector increases continuously to reach its maximum value $\left(130^{\circ} \mathrm{C}\right)$ at the end of the step.

The solar collector inertia is rather low and it adapts itself rapidly to the inlet hot water variation. Hence, as the inlet and outlet temperatures of the solar collector vary during the sorption cycle, the efficiency varies as well as it can be seen on Fig. 5. The minimum value (0.35) is reached at the end of the desorption step and the maximum one (0.52) at the end of the pre-heating step. Hence, the efficiency is high when the energy demand is high, i.e. during the pre-heating step and the beginning of the desorption step.

4.2 In house thermal comfort

On Fig. 6, the temperature evolutions without solar A/C are reported for five days of simulation. After three days of operation the room temperature reaches $27^{\circ} \mathrm{C}$ at 11 p.m., which is directly linked to the high ambient temperature at this time $\left(28{ }^{\circ} \mathrm{C}\right.$ at $10 \mathrm{p} . \mathrm{m}$.). 
Thanks to the free cooling (available between 1 and 9 a.m.), ambient temperature decreases during the night but its minimum value is about $23^{\circ} \mathrm{C}$ at 8 a.m.. So, although resulting in a decrease of $4 \mathrm{~K}$, the free cooling is insufficient to achieve thermal comfort during night-time during heat waves even if the house insulation is at current building standards. Indeed, the thermoneutral temperature is reported to be about $22{ }^{\circ} \mathrm{C}$ at $50 \% \mathrm{RH}$ for people sleeping with bedding during summer (Lin and Deng, 2008).

When adsorption cooling is available (Fig. 7), the room temperature is only $22.5^{\circ} \mathrm{C}$ at 11 p.m. after three days while the minimum is $21^{\circ} \mathrm{C}$ at 8 a.m.. Hence the thermal comfort is fulfilled despite several days of heat waves since the indoor temperature is always less than $23{ }^{\circ} \mathrm{C}$.

During daytime, the floor behaves as a cold storage: its temperature swings between 20 and $18^{\circ} \mathrm{C}$. It has to be noticed that $18^{\circ} \mathrm{C}$ is the minimum acceptable temperature to avoid moisture condensation. Indeed, for this location, the design parameter for humidity is about 10-11 g/kgair, which corresponds to a dew-point temperature of about $14-16{ }^{\circ} \mathrm{C}$.

The stored cold is transferred to the room after 8 p.m. when solar radiation (about $300 \mathrm{~W} / \mathrm{m}^{2}$ ) becomes too low to run the adsorption unit. The energy received by the floor between 8 p.m. $\left(\mathrm{T}_{\text {floor }}=18{ }^{\circ} \mathrm{C}\right)$ and 8:30 a.m. $\left(\mathrm{T}_{\text {floor }}=20^{\circ} \mathrm{C}\right)$ is equal to $75 \mathrm{MJ}$ which represents about 1.35 time the internal and external loads (55 MJ) during this period. The heat exchanged by heat loss through the walls between 2 a.m. and 8:30 a.m. is only about 4 MJ. It has to be noticed that free cooling is never used, as ambient temperature is always at least $2 \mathrm{~K}$ higher than indoor temperature. Hence, the temperature decrease during night-time is mainly due to the cold previously stored in the floor thanks to the adsorption unit.

\section{Results for heating}


The same numerical model is used without the equations for the adsorption unit. In this case, the solar panels and the floor are directly connected. The parameters are kept identical except for $\dot{Q}_{\text {indoor }}$ which is set at $0 \mathrm{~kW}$ and of course no free cooling is used.

The Orly climatic data for a cold day of November are reported on Fig. 8. The maximum of solar radiation is about $600 \mathrm{~W} / \mathrm{m}^{2}$ while the ambient temperature ranges from -1 to $3.8^{\circ} \mathrm{C}$.

The solar collector performances are reported on Fig. 9. The maximum heating power is about $9 \mathrm{~kW}$ at 1 p.m. for 10 collectors and $13.6 \mathrm{~kW}$ for 16 collectors. The delivered heating capacity is not directly proportional to the number of collectors as there is a slight drop in efficiency with increasing number of panel. This is due to a higher floor temperature so that the inlet temperature of the collectors increases. It has to be noticed that in both cases, the solar collector efficiency increases quickly and exhibits a flatten profile from sunrise to sunset. The averaged daytime efficiency is 0.54 for ten collectors.

The temperature history for five consecutive days is reported on Fig. 10 for heating provided thanks to ten $\left(24,2 \mathrm{~m}^{2}\right)$ or sixteen $\left(38,7 \mathrm{~m}^{2}\right)$ collectors and for no-heating. With no-heating the indoor temperature drops below $15{ }^{\circ} \mathrm{C}$ after day 1 and below $5{ }^{\circ} \mathrm{C}$ after five days. With ten collectors, the indoor temperature is about $17^{\circ} \mathrm{C}$ at the end of day 1 while it is only $13{ }^{\circ} \mathrm{C}$ at the end of day 5 with a minimum value of $12^{\circ} \mathrm{C}$ at the end of day 4 . The floor maximum temperature decreases from $22^{\circ} \mathrm{C}$ to $17^{\circ} \mathrm{C}$ so that it remains below the maximum acceptable operating temperature for floor heating i.e. $25^{\circ} \mathrm{C}$.

Increasing the number of collectors from ten to sixteen, thermal comfort can be achieved, as the indoor temperature is $17^{\circ} \mathrm{C}$ at the end of day 5. During daytime the indoor temperature varies between $15^{\circ} \mathrm{C}$ at 8 a.m. and $18^{\circ} \mathrm{C}$ at 5 p.m. when solar heating is no more available. It 
is still at $17.6^{\circ} \mathrm{C}$ at 10 p.m. which could be taken as representative for people's bedtime. During night-time, the temperature decreases to $15^{\circ} \mathrm{C}$ which is only $2 \mathrm{~K}$ below the recommended temperature during night by the French Energy Agency (Ademe, 2007). This is achieved thanks to the heating floor, which behaves as a heat storage releasing heat when solar energy is not available.

Hence, for the studied weather conditions, primary heating can be provided with the solar collectors while additional heating coming form fossil fuels or electricity will be needed to achieve thermal comfort during daytime.

Comparing the results for air-conditioning and heating, it can be noticed that a trade-off has to be found for the installed collector area. Indeed, in our case ten collectors are sufficient to achieve thermal comfort in summer while sixteen would be needed at least to get close to it during winter. However, it is certainly suitable to operate only ten collectors with a back-upsystem for heating in winter during the few coldest days.

\section{Conclusion}

In this work we explore the possibility to use solar adsorption air conditioning during summer and direct heating during winter by means of enhanced compound parabolic solar collector. As application a simplified reference model house of $100 \mathrm{~m}^{2}$ is used.

The air conditioning mode shows promising results, as it is possible to keep the indoor temperature below $23^{\circ} \mathrm{C}$ at the end of the journey. If the adsorption unit is not used, the temperature increases from day to day to values above $27^{\circ} \mathrm{C}$ despite free-cooling during night-time. Nevertheless, this installation can be seen as oversized for the targeted 
application, as an indoor temperature of $24-25^{\circ} \mathrm{C}$ could be sufficient for thermal comfort. It has to be noticed that thanks to the CPC the thermodynamic performances are very good for this kind of installation as we obtain a mean solar COP of 0.23 from 9 a.m. to 9 p.m.

The solar collectors were directly used for heating during the cold season. To reach thermal comfort, an increased number of collectors is needed compared to the one needed for airconditioning. Nevertheless, the installation is able to heat the house during most days but it will provide only a fraction of heating needs during the coldest days so that saving on electricity or fossil fuel consumption will be possible.

The potential of such installation has been demonstrated with this work highlighting the interest of solar driven air-conditioning systems together with solar heating. Indeed, these systems allow using solar collectors around the year, which make the installation of solar collectors more attractive from a financial point of view.

Nevertheless, further work is needed to determine more precisely the cases for which such systems are competitive. The main leads are:

- to integrate the total cold/hot energy annual needs (heating, domestic hot water, airconditioning) and to find the optimal trade-off between the heating and cooling needs. In clod climate, heating will be the main need to take into account while it will be cooling for hot climate. Furthermore, the ratio of solar heating versus conventional heating has to be defined more precisely and will impact the profitability of the system.

- to test different solar collectors type (flat/evacuated panels, CPC) as if CPC have good performances when direct solar radiation is available, their efficiency drops rapidly when only diffuse radiation is available. On the contrary flat panels have good 
performances with diffuse solar radiation but the output hot water temperature remains below $100{ }^{\circ} \mathrm{C}$, which will have an impact on the adsorption unit performances.

- to test different house type with more detailed model allowing to take into account insulation performances, heavy/light thermal inertia, solar aspect, etc. Indeed, the reference French RT2000 house chosen for this work has insufficient thermal performances to be interesting for solar heating or cooling.

- to explore the interest of this kind of installation for different climates

\section{Acknowledgement}

This work was partially supported by the $6^{\text {th }}$ European Framework Research Program (project SoCold grant number: CT-2004-50846)

\section{Notation}

A $\quad$ area, $\mathrm{m}^{2}$

$\mathrm{C}_{\mathrm{P}} \quad$ specific heat, J/kg.K

I solar radiation, $\mathrm{W} / \mathrm{m}^{2}$

mass flowrate, $\mathrm{kg} / \mathrm{s}$

$\Delta \mathrm{H} \quad$ heat of adsorption, $\mathrm{J} / \mathrm{kg}$

L latent heat of vaporization, $\mathrm{J} / \mathrm{kg}$

M mass, kg

q adsorption capacity, $\mathrm{kg} / \mathrm{kg}_{\mathrm{ac}}$

$\mathrm{t}$ time, $\mathrm{s}$

$\mathrm{T}$ temperature, $\mathrm{K}$

$\mathrm{U}$ heat transfer coefficient, $\mathrm{W} / \mathrm{m}^{2} . \mathrm{K}$

volume flowrate, $\mathrm{m}^{3} / \mathrm{s}$ 
W lumped capacitance, $\mathrm{J} / \mathrm{K}$

subscripts

a adsorber

ac activated carbon

amb ambient/external

cd condenser

CW chilled water

d desorber

ev evaporator

f

floor floor

fresh fresh air

HW hot water

indoor indoor

$\mathrm{MeOH}$ methanol

MW cooled water

SC solar collector

wall house opaque components

win house translucent components 


\section{References}

Ademe, 2007. www.ademe.fr/particuliers/Fiches/chauffage_reg_eau/rub3.htm

Argiriou, A.A., Balaras, C.A., Kontoyiannidis, S., Michel, E., 2005. Numerical simulation and performance assessment of a low capacity solar assisted absorption heat pump coupled with a sub-floor system. Sol. Energy. 79, 290-301

Balaras, C.A., Grossman, G., Henning, H.-M., Infante Ferreira, C.A., Podesser, E., Wang, L., Wiemken, E., 2007. Solar air conditioning in Europe - An overview. Renew. Sust. Energ. Rev. 11, 299-314

Camelia, 2006. www.camelia-eu.com/

Critoph, R.E., 1988. Limitations of adsorption cycles for solar cooling. Sol. Energy. 41, 23-31

Dieng, A.O., Wang, R.Z., 2001. Literature review on solar adsorption technologies for icemaking and air-conditioning purposes and recent developments in solar technology. Renew. Sust. Energ. Rev. 5, 313-342

Henning, H.-M., 2007. Solar assisted air conditioning for buildings - an overview. Appl. Therm. Eng. 27, 1734-1749

Leite, A.P.F., Daguenet, F., 2000. Performance of a new solid adsorption ice maker with solar energy regeneration. Energe. Convers. Manage. 41, 1625-1647

Lin Z., Deng, S., 2008, A study on the thermal comfort in sleeping environments in the subtropics - Developing a thermal comfort model for sleeping environments. Energy and Buildings 43(1), 70-81

Meunier, F., 1998. Solid sorption heat powered cycles for cooling and heat pumping applications. Appl. Therm. Eng.. 18, 715-729

Nunez, T., Mittlebach, W., Henning, H.-M., 2007, Development of an adsorption chiller and heat pump for domestic heating and air-conditioning applications, Appl. Therm. Eng., 27(13), $2205-2212$

Pons, M., Poyelle, F., 1999. Adsorptive machines with advanced cycles for heat pumping or cooling applications. Int. J. Refrig. 22, 27-37

Poyelle, F., Guilleminot, J.-J., Meunier, F., 1999. Experimental tests and predictive model of an adsorptive air conditioning unit. Ind. Eng. Chem. Res. 39, 298-309

Saha, B.B., Koyama, S., Kashiwagi, T., Akisawa, A., Ng, K.C., Chua, H.T., 2003. Waste heat driven dual-mode, multi-stage, multi-bed, regenerative adsorption system. Int. J. Refrig. 26, $749-757$

Yong, L., Sumathy, K., 2004. Modeling and simulation of a solar powered two-bed adsorption air conditioning system. Energe. Convers. Manage. 45, 2761-2775 
Wang, X., Chua, H.T., Ng, K.C., 2005. Experimental investigation of silica gel-water adsorption chillers with and without passive heat recovery scheme. Int. J. Refrig. 28, 756-765

Wang, R.Z., Oliveira, R.G., 2006. Adsorption refrigeration - an efficient way to make good use of waste heat and solar energy. Prog. Energ. Combust. 32, 424-458

Zhai, X.Q., Wang, R.Z., Dai, Y.J., Wu, J.Y., Xu, Y.X., Ma, Q., 2007, Solar integrated energy system for a green building. Energy and Buildings 39(8), 985-993 
Table1: Parameters used in the simulation

\begin{tabular}{lllll}
\hline \multicolumn{2}{c}{ Adsorption Unit } & & \multicolumn{2}{c}{ House } \\
\cline { 1 - 2 } \cline { 5 - 6 } Parameter & \multicolumn{1}{c}{ Value } & & Parameter & \multicolumn{1}{c}{ Value } \\
\cline { 1 - 2 } \cline { 5 - 6 } $\mathrm{M}_{\mathrm{ac}}$ & $20 \mathrm{~kg} /$ adsorber & & $\mathrm{Q}_{\text {indoor }}$ & $1.5-0.7 \mathrm{~kW}$ \\
$\mathrm{~m}_{\mathrm{HW}}$ & $0.47 \mathrm{~kg} / \mathrm{s}$ & & $\rho \mathrm{C}_{\text {air }}$ & $0.34 \mathrm{Wh} / \mathrm{m}^{3} . \mathrm{K}$ \\
$\mathrm{m}_{\mathrm{CW}}$ & $0.5 \mathrm{~kg} / \mathrm{s}$ & & $\mathrm{UA}_{\text {floor,cooling }}$ & $0.7 \mathrm{~kW} / \mathrm{K}$ \\
$\Delta \mathrm{H}_{\mathrm{MeOH}}$ & $1344 \mathrm{~kJ} / \mathrm{kg}$ & & $\mathrm{UA}_{\text {floor,heating }}$ & $1.1 \mathrm{~kW} / \mathrm{K}$ \\
$\mathrm{L}_{\mathrm{MeOH}}$ & $1244 \mathrm{~kJ} / \mathrm{kg}$ & & $\mathrm{UA}_{\text {wall }}$ & $0.1 \mathrm{~kW} / \mathrm{K}$ \\
$\mathrm{UA}_{\mathrm{ads}}$ & $0.6 \mathrm{~kW} / \mathrm{K}$ & & $\mathrm{UA}_{\text {win }}$ & $0.04 \mathrm{~kW} / \mathrm{k}$ \\
$\mathrm{q}_{0}$ & $0.407 \mathrm{~kg} / \mathrm{kg}$ ads & & $\mathrm{W}_{\text {house }}$ & $16500 \mathrm{~kJ} / \mathrm{K}$ \\
$\mathrm{D}$ & $-3.22 .10^{-7}$ & & $\mathrm{~W}_{\text {floor }}$ & $37500 \mathrm{~kJ} / \mathrm{K}$ \\
$\mathrm{n}$ & 2.195 & & & \\
\hline
\end{tabular}




\section{$\underline{\text { Figure captions }}$}

Fig. 1: solar cooling adsorption installation sketch

Fig. 2: Orly (France) climatic data for a warm day in July

Fig. 3: Performances of the adsorption unit during daytime

Fig. 4: Solar Intensity and Evaporator, Condenser and Adsorber temperature evolutions during daytime

Fig. 5: Evaporator, Condenser, Solar Collector and Adsorber temperature evolution during a cycle

Fig. 6: Temperature evolutions without adsorption cooling unit running ( daytime; $\mathbb{Q}$ nighttime; $\odot$ free-cooling)

Fig. 7: Temperature evolutions with adsorption cooling unit running ( daytime; $\mathbb{C}$ nighttime)

Fig. 8: Orly (France) climatic data for a cold day in November

Fig. 9: Heat capacity and solar collector efficiency for day 5

Fig. 10: Room and floor temperature history during five consecutive days using 10, 16 and no solar collectors for heating ( daytime; $\mathbb{C}$ night-time) 
Figure 1 


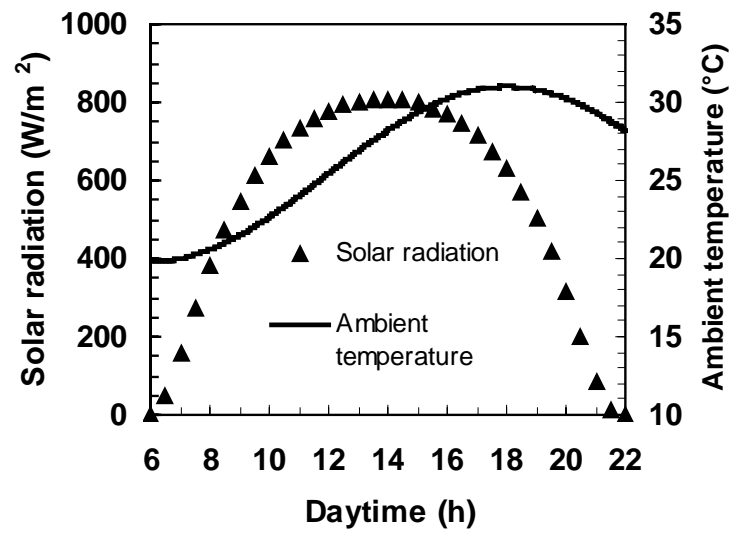

Figure 2 


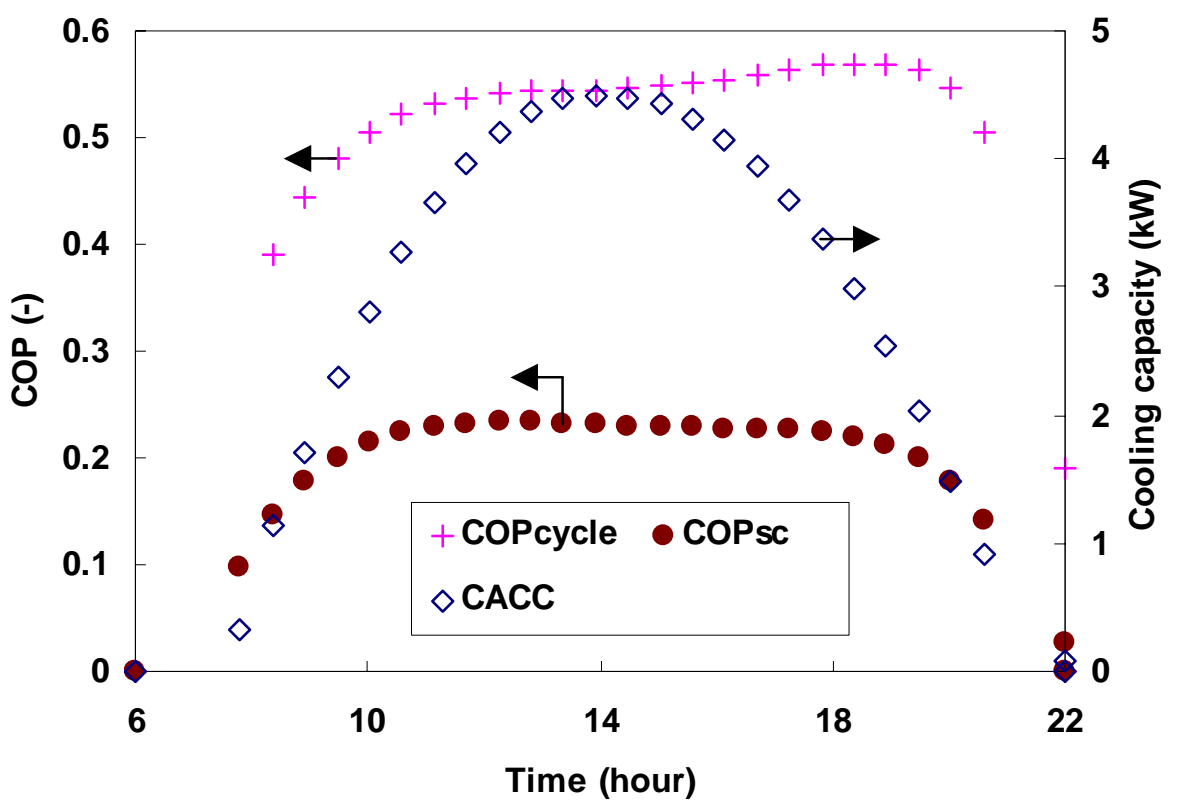

Figure 3 


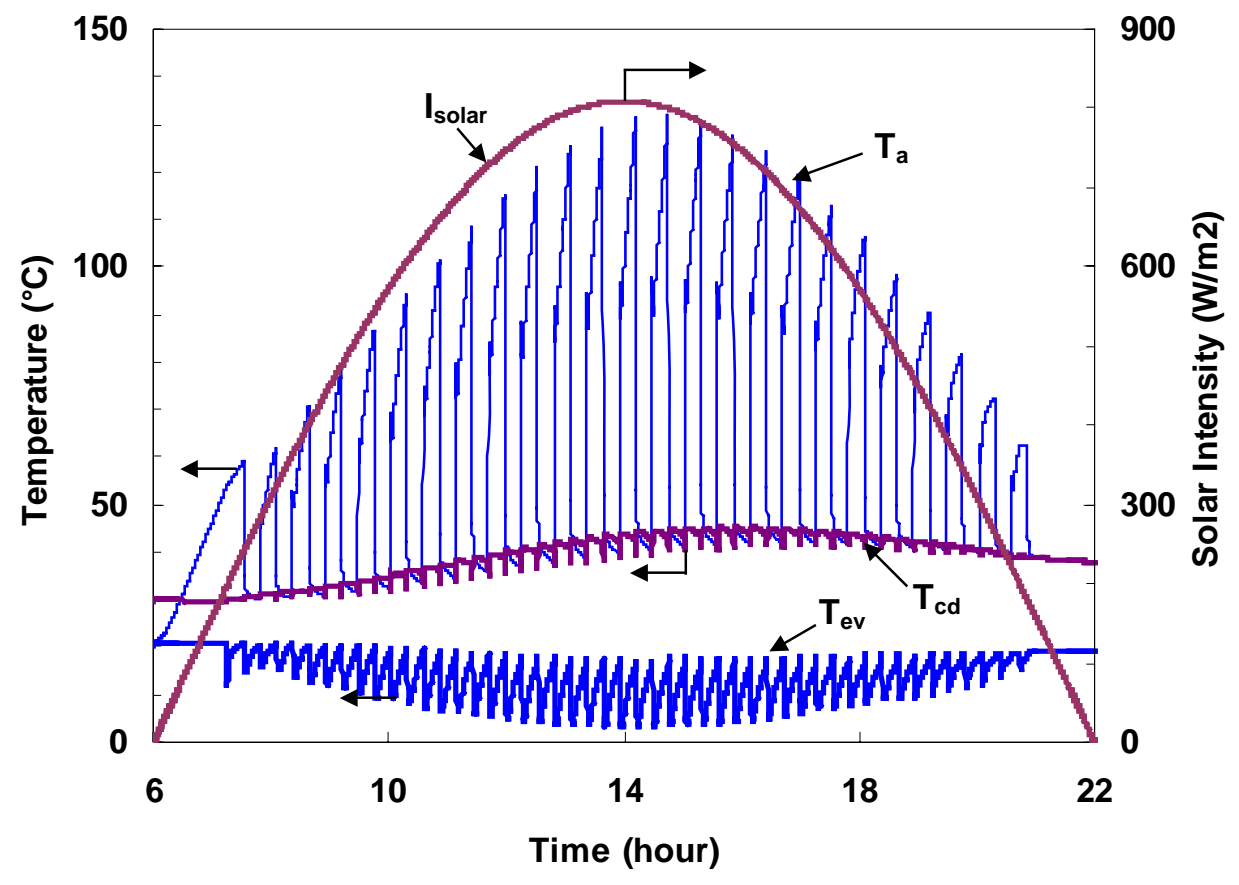

Figure 4 


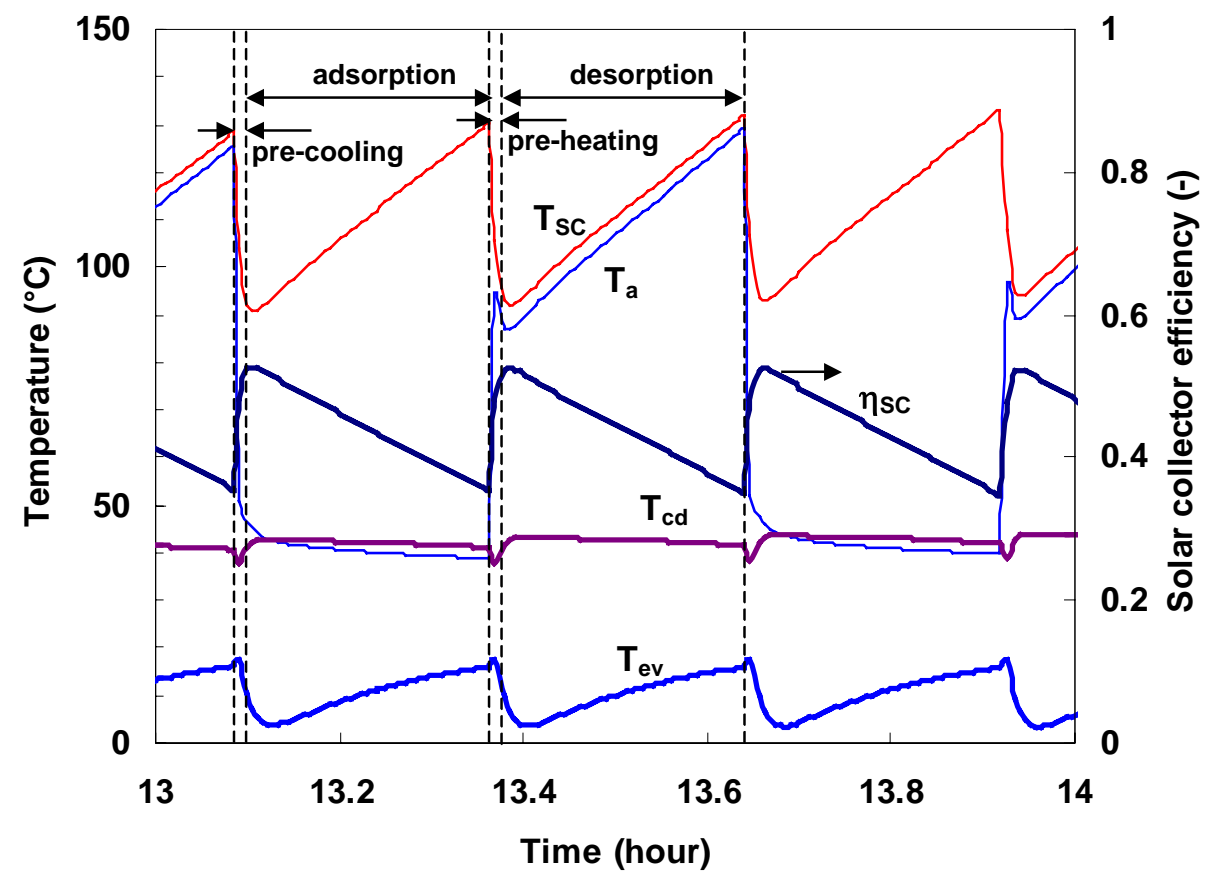

Figure 5 


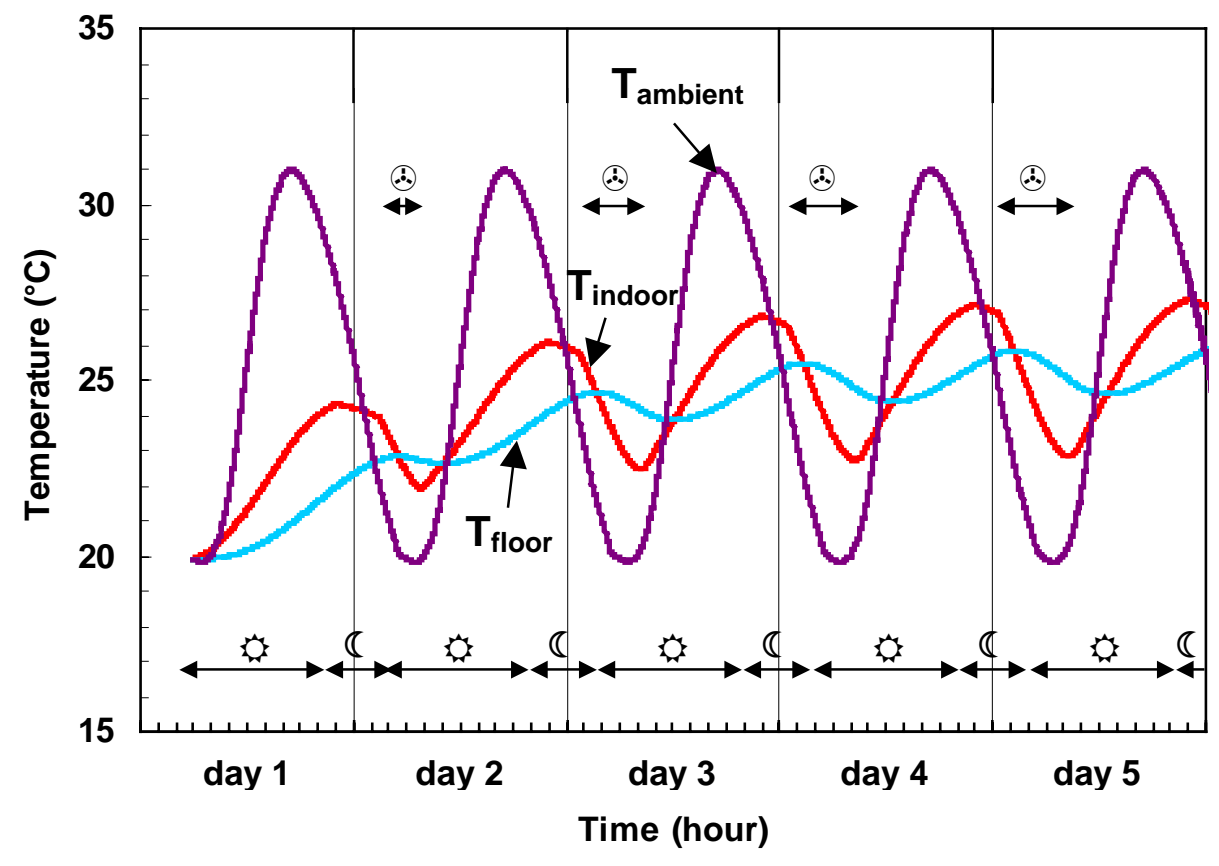

Figure 6 


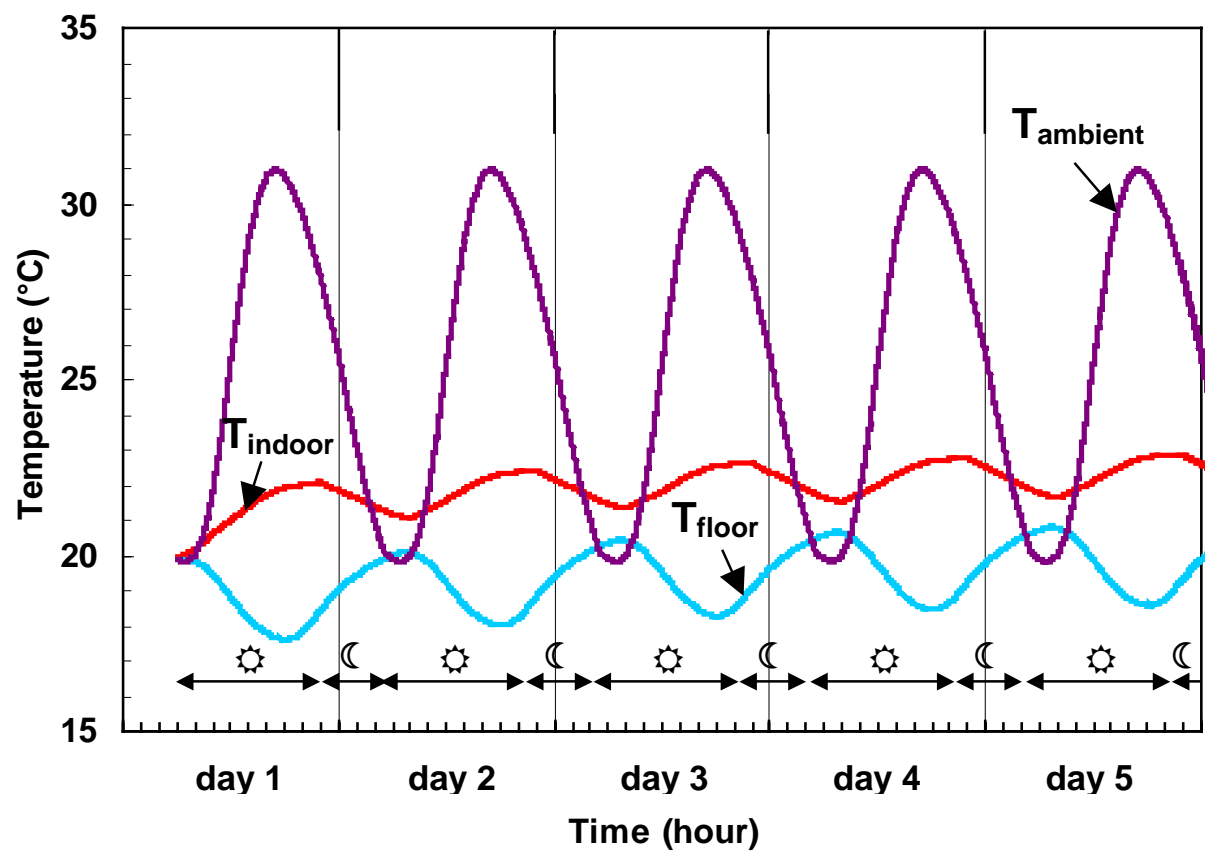

Figure 7 


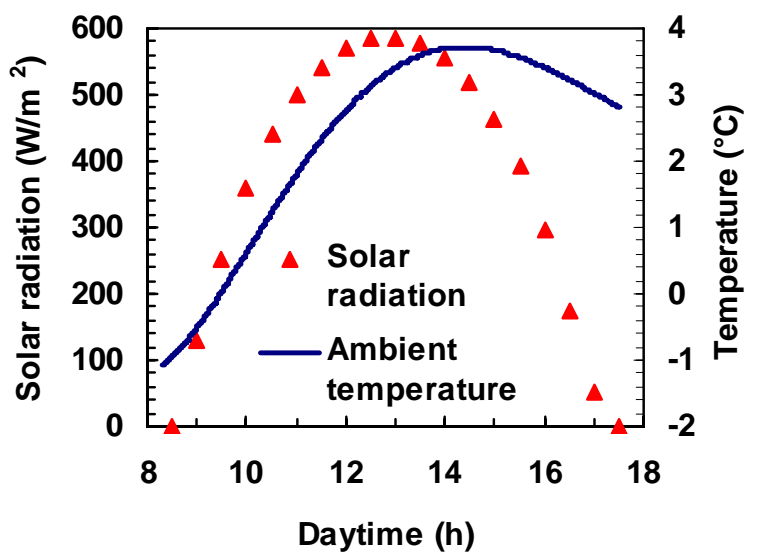

Figure 8 


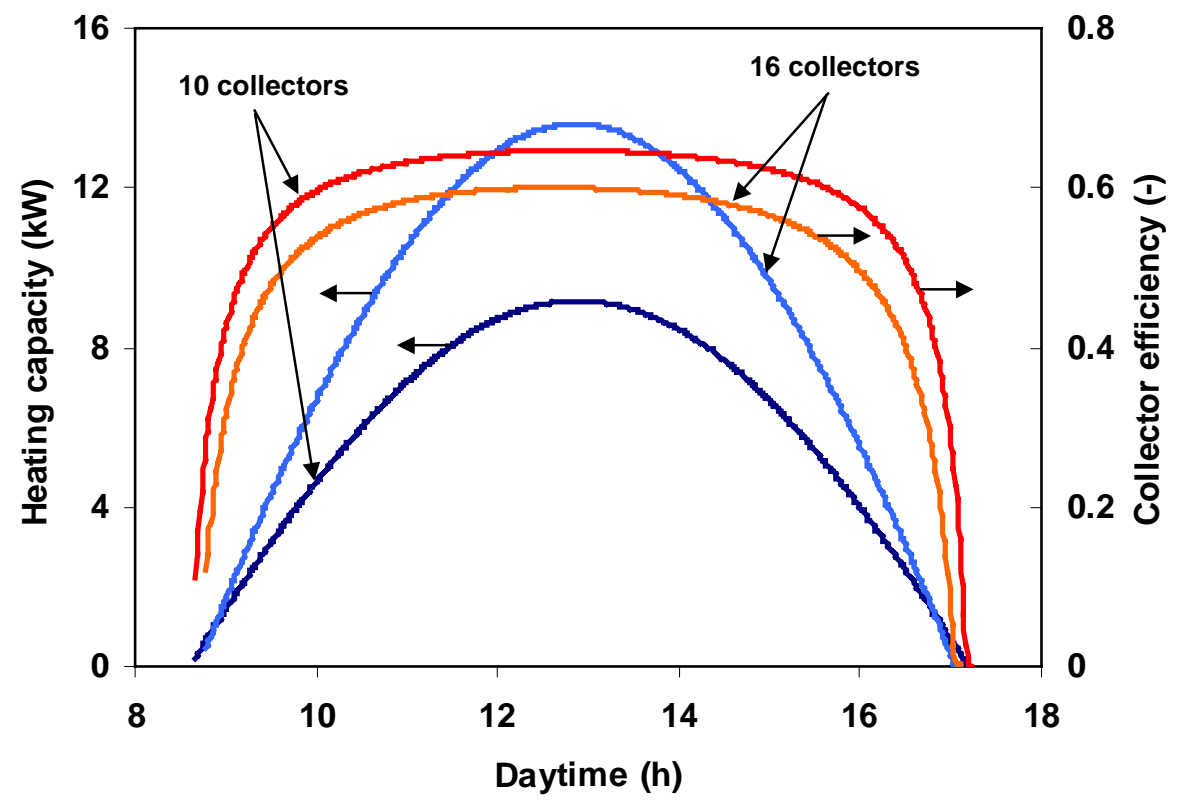

Figure 9 


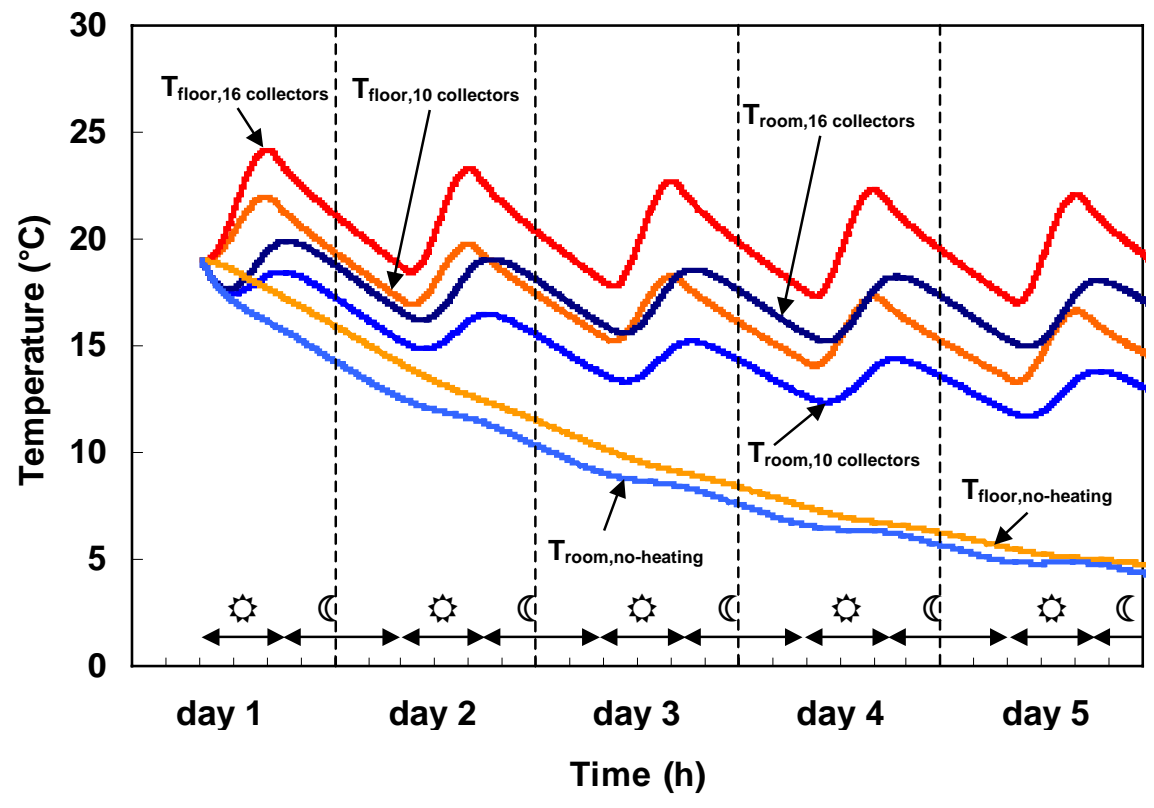

Figure 10 